\title{
Evaluation of Curriculum Implementation of 13 Sports and Health Education Teachers
}

\author{
Muslimin $^{1, *}$, Destriana $^{2}$ \\ ${ }^{1}$ Faculty of Teacher Training in Education and Language, Universitas Binadarma, Indonesia \\ ${ }^{2}$ Faculty of Teacher Training and Education, Universitas Sriwijaya, Indonesia
}

Received September 4, 2019; Revised November 30, 2019; Accepted December 4, 2019

Copyright $\mathrm{C} 2020$ by authors, all rights reserved. Authors agree that this article remains permanently open access under the terms of the Creative Commons Attribution License 4.0 International License

\begin{abstract}
This study aims to evaluate the readiness of Sports and Health Physical Education teachers regarding the implementation of the 2013 curriculum in Bantul Regency, Yogyakarta Province, Indonesia. This research method is an evaluation with the type of evaluation that is the stages of Contexts, Input, Process and Prodak. Respondents in this study were 11 Sports and Health Physical Education teachers, 267 students, 6 school principals, 1 Chair of a sports teacher association, and 1 Chair of the Education Office in Bantul Regency, Yogyakarta Province, Indonesia. This research was conducted in 2015. Data analysis techniques used quantitative descriptive techniques with percentages. The evaluation results state that the Physical Education and Sports teachers in Bantul district are ready to implement the 2013 curriculum. The conclusion based on the percentage data of $50 \%$ is in the very ready category and $50 \%$ is in the ready category. The recommendations of the results of this study are that the Physical Education and Sports teachers are ready to implement the 2013 curriculum so that it is not a problem if the Bantul Regency government implements the 2013 Curriculum.
\end{abstract}

Keywords Evaluation, Teacher, Physical Education, Sport and Health

\section{Introduction}

Education as a process of human development that lasts a lifetime, it has pedagogical objectives. Therefore, education is incomplete without physical education, sports and health, because motion as physical activity is the basis for humans to get to know the world and themselves which naturally develops in line with the times. Education in Indonesia is a system which means that the success of education in Indonesia is influenced by various things including curriculum, educators, students, facilities and infrastructure, and others, all of which are integrated to achieve the same goal of improving quality and quality education in Indonesia. The curriculum is a significant thing in regulating the implementation of education in Indonesia. The success and failure of an education is very dependent on the curriculum used. The curriculum is the spearhead for the implementation of educational activities. Without a curriculum, education is impossible to run properly, effectively, and efficiently as expected.

The Government through the Ministry of Education and Culture compiles, develops, and establishes a curriculum that applies from the 2013/2014 school year called the 2013 curriculum. The 2013 curriculum is the development of the Competency Based Curriculum that was pioneered in 2004. The 2013 curriculum emphasizes the application of scientific approaches for junior and senior high school education units and thematic approaches to primary schools with an authentic assessment system that emphasize not only student outcomes but also assessment of the process (Kemendikbud, 2012). Compared to the previous curriculum, the Education Unit Level Curriculum (KTSP), there are 4 elements that have changed in the 2013 Curriculum. These four elements are the element of graduate competency standard (SKL), element of content standard, element of process standard, and standard element assessment.

Evaluation is an activity carried out from the beginning of the development of curriculum ideas, to the time when the results of the curriculum have had an impact on society (Permendikbud 81A, 2013). Curriculum evaluation focuses on four dimensions namely ideas, documents, implementation, and results. An evaluation of the two dimensions, namely ideas and designs, was carried out during the development process while for the evaluation of the implementation of the curriculum it was aimed at reviewing the designs made by the education unit, learning implementation plan (RPP), and learning activities. The 
research of Octaviansyah et al (2015) concluded that the results of the study showed that the analysis of standard content indicators obtained a percentage of $80.1 \%$, including the appropriate category, the analysis of standard process indicators obtained a percentage of $80.7 \%$, including the appropriate category, and the analysis of standard assessment indicators obtained a percentage of $79.7 \%$ included in the appropriate category. Overall results show that the implementation of the 2013 curriculum related to content standards, process standards, and assessment standards in the teaching of physical education in Palembang City Junior High Schools has been in accordance with the 2013 curriculum implementation guidelines, but there are still difficulties experienced by teachers in implementing the 2013 curriculum related to 3 standards the. Meanwhile, according to the results of Suherman's research (2014) the results showed that the implementation of the 2013 curriculum was not in accordance with the demands of the school and even seemed to make it difficult for teachers, therefore to improve the quality of the learning process it was recommended to teachers to understand more about the implementation of the 2013 curriculum and to principals and parties related to complete learning facilities and infrastructure to improve the quality of the process and maximum learning outcomes.

Pranawati and Tuasikal's research (2014) results of this study indicate that an average of $80 \%$ of the Teaching and Learning Process has been carried out in accordance with the 2013 curriculum, in this case target junior high schools in Mojokerto, namely SMPN 1, SMPN 2, SMPN 3, SMPN 4, and SMPN 6 Mojokerto, which is based on the results of calculating the percentage of several instruments in the form of questionnaires that are filled out and intended (1) Instruments for Penjasorkes teachers, (2) Instruments for students, (3) Instruments for school principals, (4) Instruments for school committees, (5) Instrument for supervisors. The Teaching and Learning Process of Penjasorkes in the Mojokerto City Junior High School target has been carried out according to the 2013 curriculum, although it has not been fully able to run well. Alaswati Research, Setya R, Eunike RR (2106) with the results of research (1) the implementation of learning 2013 Curriculum Physical Education Sports and Health in junior high schools in Kendal District has been well implemented, (2) the potential in student activities, learning time, learning books, weaknesses in assessment techniques, infrastructure, obstacles in changing the mindset of teachers, and challenges for students to enjoy playing sports. (3) The solution for schools is to enable MGMP, in collaboration with committees, and the Education Office conducts workshops and mentors subject teachers. Conclusions: The 2013 curriculum in junior high schools has been running and obstacles can be overcome both inside and outside the school by finding solutions. This study was conducted to determine the extent to which the curriculum implementation process was able to achieve the expected competencies of students (Permendikbud 81 A, 2013).

Evaluation is done not only to see how the curriculum is implemented by Sports and Health Physical Education teachers, but the evaluation can also see whether the curriculum can effectively increase student physical activity. As in the research of Domínguez, M. Pino DP, and Aurora MV (2015) who conducted research on evaluating the performance of students' motor movements in physical education learning in schools, with the results that in general, the results showed that motor creativity, especially fluency and flexibility, increased with development through school physical education learning, even though various aspects of creativity show certain differences. In particular, motor movement increases especially rapidly between ages 6 and 9 years, and symbolic transformation of objects and movements between ages 8 and 11 years.

From some of the results of the research conducted above correlate with this study, the research aims to evaluate the implementation of the K13 curriculum of Physical Education Sports and Health in the Bantul district of the Special Province of Yogyakarta. The differentiator from the other research is the wider research area by evaluating the Physical and Physical Education Teacher in Bantul Regency.

\section{Research Method}

This research is a descriptive qualitative research method using the CIPP model approach (context, input, process, product). As revealed by Mulyatiningsih (2012) that the evaluation model is carried out systematically to be implemented with the right steps.

\subsection{Data}

The data in this study are quantitative, and the analysis technique used in this study is a descriptive analysis technique then interpreted.

\subsection{Research Instruments}

Data collection instruments are tools that are selected and used by researchers in their activities. Collect data so that these activities become complicated and simplified by it (Suharsimi Arikunto, 2010: 265). The instrument used in this study was to use the perception questionnaire of physical education, sports and health teachers, education offices, olaraga teacher associations, students, about learning physical learning. According Suharsimi Arikunto (2013: 194) questionnaire is a written question that is used for. 


\subsection{Data Collection Technique}

Data collection techniques were used in this study by providing questionnaires to respondents. As for the sequence of techniques for taking data in this study is by distributing questionnaires to respondents who have been determined namely, physical and health education teachers, students, sports teacher associations, and education offices.

\subsection{Data Analysis Technique}

The data in this study are quantitative, and the analysis technique used in this study is a descriptive analysis technique then interpreted, in this calculation also carried out by using SPSS computer assistance. Following is the description of the formula used for each item in the questionnaire using a percentage, according to Anas Sudijono (2012: 43) with the formula:

$$
\mathrm{p}=\frac{f}{\mathrm{~N}} \times 100 \%
$$

Information:

$\mathrm{p}=$ percentage rate

$\mathrm{f}=$ Frequency being sought

$\mathrm{N}=$ Number of Cases (Amount frequency / number of individuals)

\section{Results and Discussion}

\subsection{Teacher of Physical Education for Sport and Health}

\subsubsection{Contex Evaluations}

Education teachers in the Implementation of the 2013 Curriculum is in Bantul Regency, Yogyakarta Province, Indonesia.

Furthermore, the evaluation context in Bantul Regency, Yogyakarta Province Indonesia is categorized into four categories: very ready, ready, less ready, and not ready. Based on the frequency distribution of the readiness context of the Physical and Physical Education teachers in implementing the 2013 Curriculum a table can be made:

Table 1. Frequency distribution of Physical and Physical Education teachers' readiness context in the implementation of 2013 Curriculum

\begin{tabular}{|c|c|c|c|}
\hline Limitation & Percentage & Frequency & Categories \\
\hline $\mathrm{X} \geq 52$ & Very ready & 6 & $54,55 \%$ \\
\hline $40 \leq \mathrm{X} 52$ & Ready & 5 & $45,45 \%$ \\
\hline $28 \leq \mathrm{X}<40$ & Not ready enough & 0 & $0 \%$ \\
\hline $\mathrm{X}<27$ & Not ready & 0 & $0 \%$ \\
\hline
\end{tabular}

Based on the table, it can be seen that the answers of respondents $54.55 \%$ are in the category of very ready, 45 ,
$45 \%$ ready. This shows that in general the Physical and Physical Education Teacher in Bantul Regency, Yogyakarta Province, Indonesia in terms of the context of the readiness for the implementation of the 2013 Curriculum is in the very ready category. The table above shows the tendency of respondents' statements on the aspects of the 2013 curriculum implementation readiness context in Bantul Regency, Yogyakarta Province, Indonesia is in the very ready category. This shows that in general respondents gave a statement that the context in the preparation of the implementation of the 2013 Curriculum in Bantul Regency, Yogyakarta Province, Indonesia was very ready.

\subsubsection{Input Evaluations}

Input of Sports and Health Physical Education readiness in the Implementation of 2013 Curriculum in Bantul Regency, Yogyakarta Province, Indonesia. Referring to the categorization, the statement of input Sport Physical and Health Education in Bantul Regency, Yogyakarta Province, Indonesia can be identified and presented in the following table:

Table 2. Input of Physical and Physical Education teachers readiness in the 2013 Curriculum Implementation

\begin{tabular}{|c|c|c|c|}
\hline Limitation & Percentage & Frequency & Categories \\
\hline $\mathrm{X} \geq 182$ & Very ready & 8 & $72,73 \%$ \\
\hline $140 \leq \mathrm{X} 182$ & Ready & 3 & $27,27 \%$ \\
\hline $98 \leq \mathrm{X}<140$ & $\begin{array}{c}\text { Not ready } \\
\text { enough }\end{array}$ & 0 & $0 \%$ \\
\hline $\mathrm{X}<98$ & Not ready & 0 & $0 \%$ \\
\hline
\end{tabular}

By referring to the evaluation criteria compiled previously, in the table above can be seen the answers of respondents Physical Education Sports and Health in Bantul Regency Yogyakarta Province Indonesia as much as $72.73 \%$ ( 8 respondents) are in the category of very ready, $27.27 \%$ (3 respondents) are in the ready category. This shows that in general Sports and Health Physical Education in Bantul Regency, Yogyakarta Province, Indonesia, in terms of input, the preparation of the 2013 Curriculum is in the very ready category.

The table above shows the tendency of respondents' statements regarding input aspects of the 2013 curriculum implementation readiness is in the high category. This shows that in general respondents gave a statement that the input in the implementation of the 2013 Curriculum in Bantul was very good.

\subsubsection{Process Evaluation}

Referring to the categorization, the results of the questionnaire assessment of the Physical and Physical Education context in Bantul Regency, Yogyakarta Province, Indonesia can be identified and presented in the following table: 
Table 3. The Physical and Physical Education teachers Process in Implementing the 2013 Curriculum

\begin{tabular}{|c|c|c|c|}
\hline Limitation & Percentage & Frequency & Categories \\
\hline $\mathrm{X} \geq 76$ & Very ready & 2 & $18,18 \%$ \\
\hline $58 \leq \mathrm{X} 76$ & Ready & 9 & $81,82 \%$ \\
\hline $40 \leq \mathrm{X}<58$ & Not ready enough & 0 & $0 \%$ \\
\hline $\mathrm{X}<40$ & Not ready & 0 & $0 \%$ \\
\hline
\end{tabular}

By referring to the evaluation criteria compiled previously, in the table above we can see the answer to Physical Education in Sport and Health in Bantul Regency, Yogyakarta Province in Indonesia as much as $18.18 \%$ (2 respondents) in the very ready category, $82.82 \%$ ( 9 respondents) are in the ready category. This shows that in general Sports and Health Physical Education in the Bantul Regency of Yogyakarta Province of Indonesia in terms of the process of preparing the 2013 Curriculum is in the ready category.

\subsubsection{Product Evaluation}

Referring to the categorization, the results of the questionnaire assessment of Physical and Sports Education products in Bantul Regency, Yogyakarta Province, Indonesia can be identified and presented in the following table:

Table 4. The Physical Education in Sport and Health teachers Product in implementing the 2013 Curriculum

\begin{tabular}{|c|c|c|c|}
\hline Limitation & Percentage & Frequency & Categories \\
\hline $\mathrm{X} \geq 85$ & Very ready & 3 & $27,27 \%$ \\
\hline $65 \leq \mathrm{X} \mathrm{85}$ & Ready & 8 & $72,73 \%$ \\
\hline $46 \leq \mathrm{X}<65$ & Not ready enough & 0 & $0 \%$ \\
\hline $\mathrm{X}<46$ & Not ready & 0 & 0 \\
\hline
\end{tabular}

By referring to the evaluation criteria compiled previously, in the table above can be seen the answers of respondents Physical Education Sports and Health in Bantul Regency Yogyakarta Province Indonesia as much as $27.27 \%$ ( 3 respondents) are in the very ready category, $72.73 \%$ ( 8 respondents) are in the ready category. This shows that in general Sports and Health Physical Education in Bantul Regency, Yogyakarta Province, Indonesia, evaluating products for the implementation of 2013 Curriculum are in the ready category.

The table above shows the tendency of respondents' statements regarding the evaluation aspects of the 2013 curriculum implementation readiness is in the medium category. This shows that in general respondents gave a statement that the product evaluation was in readiness for the implementation of 2013 Curriculum in Bantul Regency in the ready category. It can be concluded that the average CIPP evaluation results obtained $43.18 \%$ in the very ready category and $56.82 \%$ in the ready category, it can be concluded that the evaluation results obtained through the Sports and Health Physical Education questionnaire in Bantul Regency, Yogyakarta Province, Indonesia, are obtained that Sports and Health Physical Education in
Bantul Regency, Yogyakarta Province, Indonesia is ready to use the 2013 curriculum.

\subsection{Learners}

\subsubsection{Input Evaluation Student}

Referring to the categorization, the results of the assessment of Sports and Health Physical Education input questionnaire in Bantul Regency, Yogyakarta Province, Indonesia can be identified and presented in the following table:

Table 5. Student Input Data in Bantul Regency, Yogyakarta Province, Indonesia

\begin{tabular}{|c|c|c|c|}
\hline Limitation & Percentage & Frequency & Categories \\
\hline $\mathrm{X} \geq 98$ & Very ready & 178 & $66,67 \%$ \\
\hline $75 \leq \mathrm{X} 98$ & Ready & 88 & $32,96 \%$ \\
\hline $52 \leq \mathrm{X}<75$ & Not ready enough & 1 & $0,37 \%$ \\
\hline $\mathrm{X}<52$ & Not ready & 0 & $0 \%$ \\
\hline
\end{tabular}

By referring to the input evaluation criteria compiled previously, in the table above it can be seen that the respondents' answers of students gave statements to the readiness of Physical Education and Sports in Bantul Regency, Yogyakarta Province, Indonesia, in the evaluation of inputs of $66.67 \%$ (178 respondents) in the very category ready, $32.96 \%$ ( 88 respondents) were in the ready category, $0.37 \%$ ( 1 respondent). This shows that in general the statement of the school principal about Physical Education in Sport and Health in Bantul Regency, Yogyakarta Province, Indonesia, in terms of input readiness for the implementation of 2013 Curriculum in Bantul Regency is in the category of very ready.

By referring to the categorization, the results of the student questionnaire assessment of the evaluation of Physical and Physical Education products in Bantul Regency, Yogyakarta Province, Indonesia can be identified and presented in the following table:

Table 6. Student Questionnaire Input Data in Bantul Regency, Yogyakarta Province, Indonesia

\begin{tabular}{|c|c|c|c|c|c|}
\hline No & Aspects assessed & \multicolumn{4}{|c|}{$\begin{array}{c}\text { Percentage of Respondents } \\
\text { based on the choice of answers }\end{array}$} \\
\hline & Product Evaluation & 4 & 3 & 2 & 1 \\
\hline 1 & $\begin{array}{c}\text { Implementation of } \\
\text { learning }\end{array}$ & 45,99 & 50,18 & 3,83 & 0 \\
\hline 2 & $\begin{array}{c}\text { Student learning } \\
\text { outcomes }\end{array}$ & 26,83 & 59,58 & 12,89 & 0,7 \\
\hline
\end{tabular}

The percentage is very ready to get $36.41 \%$, and $54.88 \%$ ready so that it can be concluded that the product evaluation is obtained in the ready category. The table above shows the tendency of student respondents' statements regarding the evaluation aspects of the product of the 2013 curriculum implementation readiness is in the medium category. This shows that in general the statements of student respondents gave statements that the product was in readiness for the implementation of the 
2013 Curriculum in Bantul in the ready category.

It can be concluded that the evaluation results obtained from students about the readiness of the Physical and Physical Education teachers in Bantul district based on an average of $51.54 \%$ are very ready and $43.92 \%$ are in the ready category, so it can be concluded that Physical Education and Sports Health in Bantul Regency, Yogyakarta Province, Indonesia is ready to use the 2013 curriculum.

\subsection{Sports and Health Physical Education Teachers Association}

By referring to the categorization, the results of the questionnaire assessment of the head of the Physical and Physical Education Teacher Association of the Physical and Health Education context evaluation in Bantul Regency, Yogyakarta Province, Indonesia can be identified and presented in the following table:

Table 7. Sports and health physical education teachers association context in Bantul regency, Yogyakarta province, Indonesia

\begin{tabular}{|c|c|c|c|}
\hline Limitation & Percentage & Frequency & Categories \\
\hline$X \geq 29$ & Very ready & 0 & $0 \%$ \\
\hline $23 \leq X 29$ & Ready & 1 & $100 \%$ \\
\hline $17 \leq X<23$ & Not ready enough & 0 & $0 \%$ \\
\hline$X<17$ & Not ready & 0 & $0 \%$ \\
\hline
\end{tabular}

By referring to the context evaluation criteria compiled previously, in the table above can be seen the respondent's answer chairman of the Sports and Health Physical Education Teachers Association gave a statement on the readiness of Physical Education and Sports in Bantul Regency Yogyakarta Province of Indonesia in the context evaluation of $100 \%$ ( 1 respondent) in the medium category. This shows that in general the statement of the Chairperson of the Sports and Health Physical Education Teachers Association regarding Physical Education Sports and Health in the Bantul Regency of Yogyakarta Province of Indonesia in terms of evaluating the context of the readiness for implementing the 2013 Curriculum in Bantul Regency is in the ready category.

Referring to the categorization, the results of the assessment of Sports and Health Physical Education input questionnaire in Bantul Regency, Yogyakarta Province, Indonesia can be identified and presented in the following table:

Table 8. Sports and health physical education teachers association questionnaire assessment of Physical Education in Sport and Health teacher input

\begin{tabular}{|c|c|c|c|}
\hline Limitation & Percentage & Frequency & Categories \\
\hline $\mathrm{X} \geq 162,5$ & Very ready & 1 & $100 \%$ \\
\hline $125 \leq \mathrm{X} 162,5$ & Ready & 0 & $0 \%$ \\
\hline $87,5 \leq \mathrm{X}<125$ & Not ready enough & 0 & $0 \%$ \\
\hline $\mathrm{X}<87,5$ & Not ready & 0 & $0 \%$ \\
\hline
\end{tabular}

The table above shows the tendency of the statement of the chairperson of the Sports and Health Physical Education Teachers' Association to the evaluation aspects of the 2013 curriculum implementation readiness to be in the high category. This shows that the respondent chairman of the Sports and Health Physical Education Teachers Association stated that the input in the preparation of the 2013 Curriculum in Bantul Regency was very ready.

Referring to the categorization, the results of the assessment process of the teacher's Physical Education and Sports process can be identified and presented in the following table:

Table 9. Sports and health physical education teachers association Questionnaire Assessment of Physical Education in Sport and Health Teacher Process

\begin{tabular}{|c|c|c|c|}
\hline Limitation & Percentage & Frequency & Categories \\
\hline $\mathrm{X} \geq 68,25$ & Very ready & 0 & $0 \%$ \\
\hline $52,5 \leq \mathrm{X} 68,25$ & Ready & 1 & $100 \%$ \\
\hline $36,75 \leq \mathrm{X}<52,5$ & $\begin{array}{c}\text { Not ready } \\
\text { enough }\end{array}$ & 0 & $0 \%$ \\
\hline $\mathrm{X}<36,75$ & Not ready & 0 & $0 \%$ \\
\hline
\end{tabular}

The table above shows the tendency of respondents' statements of the Association of Physical and Physical Education Teachers for Sports and Health evaluating the process of implementing the 2013 curriculum being in the medium category. This shows that in general the statements of respondents of the Sports and Health Physical Education Teachers Association stated that the process of preparing the 2013 Curriculum in Bantul was in the ready category.

Referring to the categorization, the results of the Sports and Health Physical Education questionnaire assessment process in Bantul Regency, Yogyakarta Province, Indonesia can be identified and presented in the following table:

Table 10. Sports and health physical education teachers association Questionnaire Assessment of Physical Education in Sport and Health Teacher Product

\begin{tabular}{|c|c|c|c|}
\hline Limitation & Percentage & Frequency & Categories \\
\hline $\mathrm{X} \geq 68,25$ & Very ready & 0 & $0 \%$ \\
\hline $52,5 \leq \mathrm{X} 68,25$ & Ready & 1 & $100 \%$ \\
\hline $36,75 \leq \mathrm{X}<52,5$ & $\begin{array}{c}\text { Not ready } \\
\text { enough }\end{array}$ & 0 & $0 \%$ \\
\hline $\mathrm{X}<36,75$ & Not ready & 0 & $0 \%$ \\
\hline
\end{tabular}

The table above shows the tendency of the statement of the chairperson of the Sports and Health Physical Education Teachers Association aspects of the evaluation process of the implementation of the 2013 curriculum being in the medium category. This shows that in general the statements of school principals gave statements that the products in readiness for the implementation of the 2013 curriculum in Bantul Regency were in the ready category.

It can be concluded from the results of the CIPP evaluation it is found that the percentage of $25 \%$ is in the 
very ready category, and $75 \%$ is in the ready category, then the evaluation results obtained from the head of the Bantul Regency Physical and Physical Education Teachers Association regarding the readiness of Sports and Health Physical Education in Bantul Regency Yogyakarta Indonesia in implementing the 2013 curriculum is ready.

\subsection{Headmaster}

By referring to the categorization, the results of the principal's questionnaire assessment of the evaluation of the Physical Education and Sports context in Bantul Regency, Yogyakarta Province, Indonesia can be identified and presented in the following table:

Table 11. School Principal Questionnaire Assessment of Physical Education in Sport and Health Teacher Context

\begin{tabular}{|c|c|c|c|}
\hline Limitation & Percentage & Frequency & Categories \\
\hline $\mathrm{X} \geq 29$ & Very ready & 5 & $83,33 \%$ \\
\hline $23 \leq \mathrm{X} 29$ & Ready & 1 & $16,67 \%$ \\
\hline $17 \leq \mathrm{X}<23$ & Not ready enough & 0 & $0 \%$ \\
\hline $\mathrm{X}<17$ & Not ready & 0 & $0 \%$ \\
\hline
\end{tabular}

By referring to the context evaluation criteria compiled previously, in the table above it can be seen that the respondent's answer from the principal gave a statement on the readiness of Physical Education and Sports in Bantul Regency, Yogyakarta Province, Indonesia in the context evaluation of $83.33 \%$ (5 respondents) in the very category ready, $16.67 \%$ ( 1 respondent) are in the ready category. This shows that in general the principal's statement about the Physical Education and Sports teachers in terms of evaluating the context of the implementation of the 2013 Curriculum in Bantul is in the very ready category.

Referring to the categorization, the results of the assessment of Sports and Health Physical Education input questionnaire in Bantul Regency, Yogyakarta Province, Indonesia can be identified and presented in the following table:

Table 12. School Principal Questionnaire Assessment of Physical Education in Sport and Health Teacher Input

\begin{tabular}{|c|c|c|c|}
\hline Limitation & Percentage & Frequency & Categories \\
\hline $\mathrm{X} \geq 162,5$ & Very ready & 3 & $50 \%$ \\
\hline $125 \leq \mathrm{X} 162,5$ & Ready & 3 & $50 \%$ \\
\hline $87,5 \leq \mathrm{X}<125$ & Not ready enough & 0 & $0 \%$ \\
\hline $\mathrm{X}<87,5$ & Not ready & 0 & $0 \%$ \\
\hline
\end{tabular}

By referring to the input evaluation criteria compiled previously, in the table above it can be seen that the respondent's answer from the school principal gave a statement on the readiness of Physical Education and Sports in Bantul Regency, Yogyakarta Province, Indonesia, in the evaluation of inputs by $50 \%$ (3 respondents) in the very ready category, $50 \%$ (3 respondents) are in the medium category. This shows that in general the principal's statement about Physical Education in Sport and Health in Bantul Regency, Yogyakarta Province, Indonesia, in terms of input readiness for the implementation of 2013 Curriculum in Bantul Regency is in the ready category

By referring to the categorization, the results of the school principal's questionnaire evaluation of the evaluation of the Physical Education and Sports process in Bantul Regency, Yogyakarta Province, Indonesia can be identified and presented in the following table:

Table 13. School Principal Questionnaire Assessment of Physical Education in Sport and Health Teacher Process

\begin{tabular}{|c|c|c|c|c|c|}
\hline No & Aspects assessed & \multicolumn{4}{|c|}{$\begin{array}{c}\text { Percentage of Respondents } \\
\text { based on the choice of answers }\end{array}$} \\
\hline & Product Evaluation & 4 & 3 & 2 & 1 \\
\hline 1 & $\begin{array}{c}\text { Implementation of } \\
\text { learning }\end{array}$ & 66,67 & 33,33 & 0 & 0 \\
\hline 2 & $\begin{array}{c}\text { Student learning } \\
\text { outcomes }\end{array}$ & 33,33 & 66,67 & 0 & 0 \\
\hline
\end{tabular}

The table above shows the tendency of principals 'respondents' statements regarding the evaluation aspects of the 2013 curriculum implementation readiness process is in the high category. This shows that in general the statements of school principals gave statements that the process of preparing the 2013 Curriculum in Bantul was in the very ready category.

By referring to the categorization, the results of the school principal's questionnaire assessment of the evaluation of Physical Education and Sports products in Bantul Regency, Yogyakarta Province, Indonesia can be identified and presented in the following table:

Table 14. School Principal Questionnaire Assessment of Physical Education in Sport and Health Teacher Product

\begin{tabular}{|c|c|c|c|c|c|}
\hline No & Aspects assessed & \multicolumn{4}{|c|}{$\begin{array}{r}\text { Percentage of Respondents based } \\
\text { on the choice of answers }\end{array}$} \\
\hline & $\begin{array}{c}\text { Product } \\
\text { Evaluation }\end{array}$ & 4 & 3 & 2 & 1 \\
\hline 1 & $\begin{array}{c}\text { Implementation of } \\
\text { learning }\end{array}$ & 33,34 & 61,90 & 4,76 & 0 \\
\hline 2 & $\begin{array}{c}\text { Student learning } \\
\text { outcomes }\end{array}$ & 33,34 & 61,90 & 4,76 & 0 \\
\hline
\end{tabular}

The table above shows the tendency of principals 'respondents' statements regarding the evaluation aspects of the 2013 curriculum implementation readiness is in the medium category. This shows that in general the statement of the principal respondent gave a statement that the product was in readiness for the implementation of 2013 Curriculum in Bantul Regency in the ready category.

It can be concluded that the evaluation results obtained from the principal respondents were $54.17 \%$ in the very ready category and $44.65 \%$ were in the ready category, and then the conclusion was Physical Education and Sports in Bantul Regency, Yogyakarta Province, Indonesia through evaluations conducted to the principal produced PJOK teachers who are ready to implement the 2013 curriculum. 


\subsection{Data Description of Head of Sub Division of Basic Education Office}

Referring to the categorization, the results of the assessment of the respondents of the head of the basic education subdivision of the Department of Education on the context of Physical Education Sports and Health in Bantul Regency, Yogyakarta Province, Indonesia can be known and presented in the following table:

Table 15. SUb Questionnaire Evaluation for Basic Education Section on Physical Education in Sport and Health Teacher Context

\begin{tabular}{|c|c|c|c|}
\hline Limitation & Percentage & Frequency & Categories \\
\hline $\mathrm{X} \geq 29$ & Very ready & 4 & $80 \%$ \\
\hline $23 \leq \mathrm{X} 29$ & Ready & 1 & $20 \%$ \\
\hline $17 \leq \mathrm{X}<23$ & Not ready enough & 0 & $0 \%$ \\
\hline $\mathrm{X}<17$ & Not ready & 0 & $0 \%$ \\
\hline
\end{tabular}

By referring to the context evaluation criteria compiled previously, in the table above it can be seen that the respondent's answer to the head of the basic education sub-division of the Education Office gave a statement on the readiness of Physical Education in Sports and Health in Bantul Regency, Yogyakarta Province, Indonesia, in the context evaluation of $80 \%$ (4 respondents) located in the very ready category, $20 \%$ ( 1 respondent) is in the ready category. This shows that in general the statement of the head of the basic education subdivision of the Department of Education on Physical Education Sports and Health in Bantul Regency, Yogyakarta Province Indonesia in terms of the context of the readiness for the implementation of 2013 Curriculum in DIY is in the category of very ready.

Referring to the categorization, the results of the assessment of Sports and Health Physical Education input questionnaire in Bantul Regency, Yogyakarta Province, Indonesia can be identified and presented in the following table:

Table 16. SUb Questionnaire Evaluation for Basic Education Section on PJOK Teacher Input

\begin{tabular}{|c|c|c|c|}
\hline Limitation & Percentage & Frequency & Categories \\
\hline $\mathrm{X} \geq 162,5$ & Very ready & 1 & $20 \%$ \\
\hline $125 \leq \mathrm{X} 162,5$ & Ready & 4 & $80 \%$ \\
\hline $87,5 \leq \mathrm{X}<125$ & Not ready enough & 0 & $0 \%$ \\
\hline $\mathrm{X}<87,5$ & Not ready & 0 & $0 \%$ \\
\hline
\end{tabular}

Referring to the input evaluation criteria compiled previously, in the table above it can be seen that the respondent's answer from the head of the basic education sub-section of the Education Office gave a statement on the readiness of the Physical and Physical Education teachers in the input evaluation of $20 \%$ ( 1 respondent). $80 \%$ (4 respondents) so in general respondents are in the high category. This shows that in general the statement of the head of the basic education subdivision of the Department of Education on Sports Physical Education and Health in
Bantul Regency, Yogyakarta Province of Indonesia in terms of input readiness for the implementation of 2013 Curriculum in DIY is in the ready category.

Referring to the categorization, the results of the questionnaire assessment process of Physical Education and Sports teachers can be known and presented in the following table:

Table 17. SUb Questionnaire Evaluation for Basic Education Section on Physical Education in Sport and Health Teacher Process

\begin{tabular}{|c|c|c|c|}
\hline Limitation & Percentage & Frequency & Categories \\
\hline $\mathrm{X} \geq 68,25$ & Very ready & 0 & $0 \%$ \\
\hline $52,5 \leq \mathrm{X} 68,25$ & Ready & 4 & $80 \%$ \\
\hline $36,75 \leq \mathrm{X}<52,5$ & $\begin{array}{c}\text { Not ready } \\
\text { enough }\end{array}$ & 1 & $20 \%$ \\
\hline $\mathrm{X}<36,75$ & Not ready & 0 & $0 \%$ \\
\hline
\end{tabular}

Referring to the process evaluation criteria compiled previously, in the table above it can be seen that the respondent's answer from the head of the basic education sub-section gave a statement on the readiness of Sports and Health Physical Education in Bantul Regency, Yogyakarta Province, Indonesia. Ready, 20\% (1 respondent) are in the category of not ready. This shows that in general the statement of the respondents of the head of the sub-section of basic education about PJOK teachers in terms of the readiness process for implementing the 2013 curriculum in DIY is in the ready category.

Referring to the categorization, the results of the questionnaire product evaluation of the respondents of the head of the sub-section of basic education to Physical Education and Sports in Bantul Regency, Yogyakarta Province, Indonesia can be known and presented in the following table:

Table 18. SUb Questionnaire Evaluation for Basic Education Section on Physical Education in Sport and Health Teacher Product

\begin{tabular}{|c|c|c|c|}
\hline Limitation & Percentage & Frequency & Categories \\
\hline $\mathrm{X} \geq 84,5$ & Very ready & 1 & $20 \%$ \\
\hline $65 \leq \mathrm{X} 84,5$ & Ready & 4 & $80 \%$ \\
\hline $45,5 \leq \mathrm{X}<65$ & $\begin{array}{c}\text { Not ready } \\
\text { enough }\end{array}$ & 0 & $0 \%$ \\
\hline $\mathrm{X}<45,5$ & Not ready & 0 & $0 \%$ \\
\hline
\end{tabular}

Referring to the context evaluation criteria compiled previously, in the table above it can be seen that the respondent's answer from the head of the basic education sub-section gave a statement on the readiness of the Physical and Physical Education teachers in product evaluation by $20 \%$ ( 1 respondent) in the very ready category, $80 \%$ (4 respondents) are in the ready category. This shows that in general the statement of the respondents of the head of the sub-section of basic education about the Physical Education and Sports teachers in terms of the product in readiness for the implementation of the 2013 Curriculum in DIY is in the ready category 


\section{Discoustion}

Evaluation results obtained a percentage of $50 \%$ are in the very ready category and $50 \%$ are in the ready category. It can be concluded that the teacher from the evaluation results of the head of the sub-education department teacher Sports Physical and Health Education is ready to carry out the 2013 curriculum. The results of this study are in accordance with the results of research by Sultoni and Abdul RST (2015), for both schools still not fully going well. Based on the analysis, SMPN 3 Sumberasih One Roof has a percentage of $71.76 \%$ or in the sufficient category. Whereas for SMPN 5 Lumbang One Roof which is $75.72 \%$ or in the sufficient category. In the implementation, both of them still have some obstacles, namely (1) Teacher's understanding of the learning process is still lacking, (2) Training activities are felt to be still lacking, (3) Student's level of understanding, (4) Learning support infrastructure, especially in SMPN 3 Sumberasih Satu The roof is still lacking, and (5) Teachers still have difficulty in applying the assessment system. Other studies that show the evaluation of the implementation of Physical Education teachers in the K13 Quirkulum namely Nasir (2015) research results (1) The research shows that the implementation of Physical Education teachers towards the 2013 Curriculum is in the category of "High", as many as 3.96\% answered "Low", 34.78\% "Medium ", 47.63\%" High ", and 13.62\%" Very High ". (2) When viewed from each factor shows that (a) the preparation factor shows the results of "High", as many as 3.8\% answered "Low", 34.8\% "Medium", 47.0\% "High", and 14.5\% "Very High "(B) The implementation factor shows" High "results, as many as 4.9\% answered" Low ", 37.1\%" Medium ", 47.3\%" High ", and $10.8 \% "$ Very High ". (c) The evaluation factor shows a "High" result, in which as many as $1.2 \%$ answered.

\section{Conclusions}

The conclusion from this study that from the results of data analysis and discussion both from the evaluation of context, input, process and product carried out to the respondents indicated that Sports and Health Physical Education in Bantul Regency, Yogyakarta Province, Indonesia in Bantul Regency was ready to implement the K13 curriculum. The conclusion based on data percentage of $50 \%$ is in the very ready category and $50 \%$ is in the ready category. Comparative research conducted by Dedi Asmajaya.( 2019) The results of the study 1) The implementation of K13 in the subjects obtained by students obtained a context of $75.56 \%, 76.67 \%$ input, $78 \%$ process and $72.5 \%$ product. Context obtained $80 \%$, input $79.33 \%$, process $75.33 \%$ and product $74.79 \%$, overall results for students $75.77 \%$ (good category) and teachers $73.40 \%$ (good category). 2) Constraints, 24.23\% for students and $26.60 \%$ for teachers, such as lack of infrastructure support, scientific learning is not appropriate, do not understand
$\mathrm{K} 13$, lack of understanding of the use of e-report cards, and learning media have not been interesting 3) to overcome it already done complete K13 socialization and training, K13 in-on mentoring, formation of KKG / MGMP by the school principal and training for updating report cards. Conclusions in this study using an overall evaluation of $73.40 \%$ (good category), meaning that the implementation of K13 has been implemented well but there needs to be continued supervision and periodic training improvement. Mamatha H. K, Sridhar R, and Balasubramanian S (2019) the title Evaluation of Faculty Performance of Higher Education Institution Using Principal Component Analysis. In this study, the faculty performance scores (API) as per UGC format were analyzed using PCA and the most important components were identified contributing to the performance of the faculty. The study of Muslimin and Arif Hidayat (2016) with the title evaluation of the soccer coaching program at Sriwijaya State School (SONS) in South Sumatra with $63.79 \%$ conformity research results including good category.

\section{REFERENCES}

[1] Alaswati.Sri, Setya R, Eunike R.R (2106). Evaluation of the Implementation of 2013 Curriculum Learning Corner. Journal of Physical Education and Sports. JPES 5 (2). (2016) p.111-119

[2] Dedi Asmajaya. 2019. The Evaluation in Implementing the Curriculum of 2013 in Sport and Health Education Subject in State Junior High School in Percut Sei Tuan sub-district in academic year 2017/2018. Thesis. State University of Medan

[3] Domínguez, M. Pino D-P, and Aurora M-V. (2015). The evolution of motor creativity during primary Education. Journal of Human Sport \& Exercise (JHSE). ISSN 1988-5202 (C) Faculty of Education. University of Alicante. Volume 10 | Issue 2 | 2015. P.583-591. doi: 10.14198 / jhse.2015.102.05

[4] Fikri, A., Muslimin, J. T., \& MochAsmawi, W. (2009). Evaluation Program of Development and Training Center for Sports Students (PPLP) of Fencing South Sumatra. evaluation, 239.

[5] Mamatha H. K, Sridhar R, Balasubramanian S . "Evaluation of Faculty Performance of Higher Education Institution Using Principal Component Analysis." Universal Journal of Educational Research 7.11 (2019) 2270 - 2277. doi: 10.13189/ujer.2019.071104.

[6] Mulyatiningsih. Endang (2012). Applied Research in Education. Bandung: Alfabeta.

[7] Muslimin, M., \& Hidayat, A. 2016. Evaluation of the South Sumatra State Sports School Sriwijaya Football Team Coaching Program 2016. Journal Sport Area, 2 (2), 53-62.

[8] Nasir. Bahrun (2015). Implementation of 2013 Physical Education Curriculum for Elementary School Teachers in Srumbung Subdistrict, Magelang District. Health and 
Recreation Physical Education Study Program. Department of Physical Education. Faculty of Sport Science. Yogyakarta State University.

[9] Octaviansyah, Tandiyo Rahayu, Oktia Woro Kasmini Handayani. 2015. Evaluation of the implementation of the 2013 curriculum in the learning of physical education in junior high schools in the city of Palembang. Journal of Physical Education and Sports. JPES 4 (2) (2015)

[10] Sultoni.Arief. $M$ and Abdul R.S.T (2015). The implementation of the 2013 curriculum in junior high school level subjects at one-roof school on the island of Gili Ketapang and Probolinggo Regency. Journal of Sports and Health Education. Volume 03 Number 02 of 2015, 243 $-248$

[11] Suherman. Ayi (2014). Implementation of the 2013 New Curriculum for Physical Education Subjects (qualitative descriptive study in SDN Cilengkrang). Mimbar Elementary School, Volume 1 Number 1 April 2014, (pp. 71-76).

[12] Pranawati. Nela and Abdul.R.S.T. (2014). 2013 Curriculum Implementation Survey in Penjasorkes Subjects In Mojokerto City Middle School. Journal of Sports and Health Education. Volume 02 Number 03 of 2014, 657 660 